\title{
STRUCTURAL-TOPOLOGICAL SYNTHESIS OF SPACE MECHANISMS WITH RODS AND WHEELS
}

Relly Victoria Virgil Petrescu

IFToMM, Romania

E-mail: rvvpetrescu@gmail.com

Florian Ion Tiberiu Petrescu

IFTOMM, Romania

E-mail: fitpetrescu@gmail.com

Submission: 11/10/2018

Revision: 11/21/2018

Accept: 11/28/2018

\section{ABSTRACT}

Today, robots are increasingly present in the machine building industry, sometimes even in some sections to replace workers altogether, due to the high quality of their work, repetitive, without stopping or pausing, without any manufacturing and assembly scuffs. In this paper, one presents the mechanisms with bars and gears, which are planetary mechanisms for robot automation and mechatronics, structurally-topological. The gears and bars consist of at least one movable articulated bar and one of the cylindrical, tapered or hipoidal gears. Only gears with circular or straight toothed gears, in which the relative position of the rotation or translation axes does not change, shall be considered. The topological structure of the gears and gears is characterized by a kinematic chain with articulated bars and at least one kinematic chain with gears. The kinematic chain may be chain open (with a fixed rotation joint) or closed chain (with at least two fixed joints). The kinematic chain with gears is attached to the kinematic chain with bars so that at least two gear wheels have centers in the bars of the bars and some wheels may be integral with the bars. In practice, some of these gears with gears and gears are known as planetary gears with cylindrical, conical or hipoidal gears. 
INDEPENDENT JOURNAL OF MANAGEMENT \& PRODUCTION (IJM\&P)

http://www.ijmp.jor.br

V. 10, n. 5, September-October 2019

ISSN: 2236-269X

DOI: 10.14807/ijmp.v10i5.902

Keywords: Robots; Mechatronic Systems; Structure; Topology

\section{INTRODUCTION}

Today, robots are increasingly present in the machine building industry, sometimes even in some sections to replace workers altogether, due to the high quality of their work, repetitive, without stopping or pausing, without any manufacturing and assembly scuffs.

Additionally, robots do not get sick, do not require medical leave or rest, work faster and better than humans and also support toxic environments from dyers, general assemblies, etc.

Generally, robots have increased the quality and productivity of work and have not even created a union to defend their claims, demanding increased wages for them and larger holidays. Interestingly, a robot is working without a break, but without salary, without breaks, without complaining about working conditions in the plant.

Robots can work on three shifts, that is, permanently, but not by shifting them like people did, but always remaining the same robots deployed in operation, nonstop, for days, without breaks, without rest, without problems.

It has come to the effect that the big car manufacturers and even others, have entire sections in which only robots work. They do not have to worry about each other, do not quarrel, do not complain, do not cry, do not ask for the salary, do not require leave, they do not want free days and can work with high returns and Saturday and Sunday, if necessary on three shifts without a break.

The importance of implementing robots can no longer be challenged. They have so increased the quality of work and the production of an enterprise that they can no longer give up their help. Workers have reclassified themselves and work only in more friendly workplaces, or in other workplaces, such as supermarkets, in better conditions, with higher wages, with several days off and they are also pleased and all this is due to production and additional gains from higher sales due to the robot work in large factories.

We can clearly state that robots have improved our lives considerably. Thanks to them, a new free day was introduced for almost all working people, Friday, in 
INDEPENDENT JOURNAL OF MANAGEMENT \& PRODUCTION (IJM\&P)

http://Www.ijmp.jor.br

V. 10, n. 5, September-October 2019

ISSN: 2236-269X

DOI: 10.14807/ijmp.v10i5.902

addition to Saturday and we may soon be able to introduce another free day, but we have to choose whether it is Monday or Thursday.

People, in the beginning, were taught by the trade union bosses to chase and sabotage the robots, to ruin them and not to accept them. Today things are clear and the robots work quietly in the big companies and factories for the sake of everyone, so now we can all accept the silence of the automation, the robotics, the electronics, without letting us be fooled by the union leaders, who slowly slow down and they will calm down.

If we like it or not like, robots have already stolen all our hard works places.

Anthropomorphic robots are, as I have already said, in most of the most widespread and widely used works worldwide today, due to their ability to adapt quickly to forced work, working without breaks or breaks $24 \mathrm{~h}$ a day, without unpaid leave without asking for food, water, air, or salary. Anthropomorphic robots are supple, elegant, easy to configure and adapted to almost any required location, being the most flexible, more useful, more penetrating, easy to deploy and maintain.

For the first time, these robots have asserted themselves in the automotive industry and especially in the automotive industry, today they have penetrated almost all industrial fields, being easily adaptable, flexible, dynamic, resilient, cheaper than other models, occupying a volume smaller but with a major working space. They can also work in toxic or dangerous environments, so used in dyeing, chemical cleaners, in chemical or nuclear environments, where they handle explosive objects, or in military missions to land or sea mines, even if they were banned to use, because there are still countries around the globe that use them, such as Afghanistan.

The most used today's industrial robots, is built. The importance of the study of anthropomorphic robots has also been signaled, being today the most widespread robots worldwide, due to its simple design, construction, implementation, operation and maintenance. In addition, anthromomorphic systems are simpler from a technological and cheaper point of view, performing a continuous, demanding, repetitive work without any major maintenance problems.

The basic module of these robots was also presented geometrically, cinematically, of the forces, of its total static balancing and of the forces that arise within or after balancing. In the present paper we want to highlight the dynamics of the already statically balanced total module. It has been presented in other works and 
INDEPENDENT JOURNAL OF MANAGEMENT \& PRODUCTION (IJM\&P)

http://Www.ijmp.jor.br

V. 10, n. 5, September-October 2019

ISSN: 2236-269X

DOI: 10.14807/ijmp.v10i5.902

studied matrix spatially, or more simply in a plan, but in this case, it is necessary to move from the working plane to the real space, or vice versa, passage that we will present in this study.

In the basic plan module already presented in other geometric and cinematic works, we want to highlight some dynamic features such as static balancing, total balancing and determination of the strength of the module after balancing. Through a total static balancing, balancing the gravitational forces and moments generated by the forces of gravity is achieved, balancing the forces of inertia and the moments (couples) generated by the presence of inertial forces (not to be confused with the inertial moments of the mechanism, which appear separately from the other forces, being part of the inertial torsion of a mechanism and depending on both the inertial masses of the mechanism and its angular accelerations.

Balancing the mechanism can be done through various methods. Partial balancing is achieved almost in all cases where the actuators (electric drive motors) are fitted with a mechanical reduction, a mechanical transmission, a sprocket, spiral gear, spool screw type. This results in a "forced" drive balancing from the transmission, which makes the operation of the assembly to be correct but rigid and with mechanical shocks. Such balancing is not possible when the actuators directly actuate the elements of the kinematic chain without using mechanical reducers (ANTONESCU; PETRESCU, 1985; 1989; ANTONESCU et al., 1985a; 1985b; 1986; 1987; 1988; 1994; 1997; 2000a; 2000b; 2001; ATEFI et al., 2008; Avaei et al., 2008; AVERSA et al., 2017a; 2017b; 2017c; 2017d; 2017e; 2016a; 2016b; 2016c; 2016d; 2016e; 2016f; 2016g; 2016h; 2016i; 2016j; 2016k; 2016l; 2016m; 2016n; 2016o; AZAGA; OTHMAN, 2008; CAO et al., 2013; DONG et al., 2013; EL-TOUS, 2008; COMANESCU, 2010; FRANKLIN, 1930; HE et al., 2013; JOLGAF et al., 2008; KANNAPPAN et al., 2008; LEE, 2013; LIN et al., 2013; LIU et al., 2013; MEENA AND RITTIDECH, 2008; MEENA et al., 2008; MIRSAYAR et al., 2017; NG et al., 2008; PADULA; PERDEREAU; PANNIRSELVAM, 2008; 2013; PERUMAAL; JAWAHAR, 2013; PETRESCU, 2011; 2015a; 2015b; PETRESCU; PETRESCU, 1995a; 1995b; 1997a; 1997b; 1997c; 2000a; 2000b; 2002a; 2002b; 2003; 2005a; 2005b; 2005c; 2005d; 2005e; 2011a; 2011b; 2012a; 2012b; 2013a; 2013b; 2016a; 2016b; 2016c; PETRESCU et al., 2009; 2016; 2017a; 2017b; 2017c; 2017d; 2017e; 2017f; 2017g; 2017h; 2017i; 2017j; 2017k; 2017l; 2017m; 2017n; 2017o; 2017p; 2017q; 2017r; 2017s; 2017t; 2017u; 2017v; 
DOI: 10.14807/ijmp.v10i5.902

2017w; 2017x; 2017y; 2017z; 2017aa; 2017ab; 2017ac; 2017ad; 2017ae; 2018a; 2018b; 2018c; 2018d; 2018e; 2018f; 2018g; 2018h; 2018i; 2018j; 2018k; 2018l; 2018m; 2018n; POURMAHMOUD, 2008; RAJASEKARAN et al., 2008; SHOJAEEFARD et al., 2008; TAHER et al., 2008; TAVALLAEI; TOUSI, 2008; THEANSUWAN; TRIRATANASIRICHAI, 2008; ZAHEDI et al., 2008; ZULKIFLI et al., 2008).

In this paper one presents the space mechanisms with bars and gears, which are planetary mechanisms for robot automation and mechatronics, structurallytopological.

It is first considered the space mechanisms with the kernel chain with open bars.

Two groups of such spatial mechanisms are known: elementary mechanisms (with a single articulated bar) and complex articulated mechanisms (with two or more articulated bars).

Elementary space mechanisms can be made with a single central wheel (Figure 1) or two central wheels (Figure 2) whose fixed axes coincide with the axis of the fixed hinge of the bar.

\section{METHODS AND MATERIALS}

It is first considered the space mechanisms with the kernel chain with open bars.

Two groups of such spatial mechanisms are known: elementary mechanisms (with a single articulated bar) and complex articulated mechanisms (with two or more articulated bars).

Elementary space mechanisms can be made with a single central wheel (Figure 1) or two central wheels (Figure 2) whose fixed axes coincide with the axis of the fixed hinge of the bar.

The toothed wheels used in the space mechanisms are conical wheels (Figure 1a) and worm wheel with screw and worm wheel (Figure 1b).

In the spherical space mechanism (Figure 1a), the central conical wheel 1 engages the satellite cone wheel 2 , their axes being competing at the point $S$, this 
INDEPENDENT JOURNAL OF MANAGEMENT \& PRODUCTION (IJM\&P)

http://www.ijmp.jor.br

V. 10, n. 5, September-October 2019

ISSN: 2236-269X

DOI: 10.14807/ijmp.v10i5.902

being the common tip of the rolling cones. The bar 3 has two joints, one fixed in A0 (common to wheel 1), and another movable in A through which it links to wheel 2.

If the axes of the two conical wheels are perpendicular, the conical gear is called orthogonally, in this form being most often used in practice.

The mobility of the spherical mechanism is $M=2$, which is deduced by the calculation of the custom formula (1):

$$
M=C_{1}+2 C_{2}-3 N_{3}=3+2 \cdot 1-3 \cdot 1=2
$$

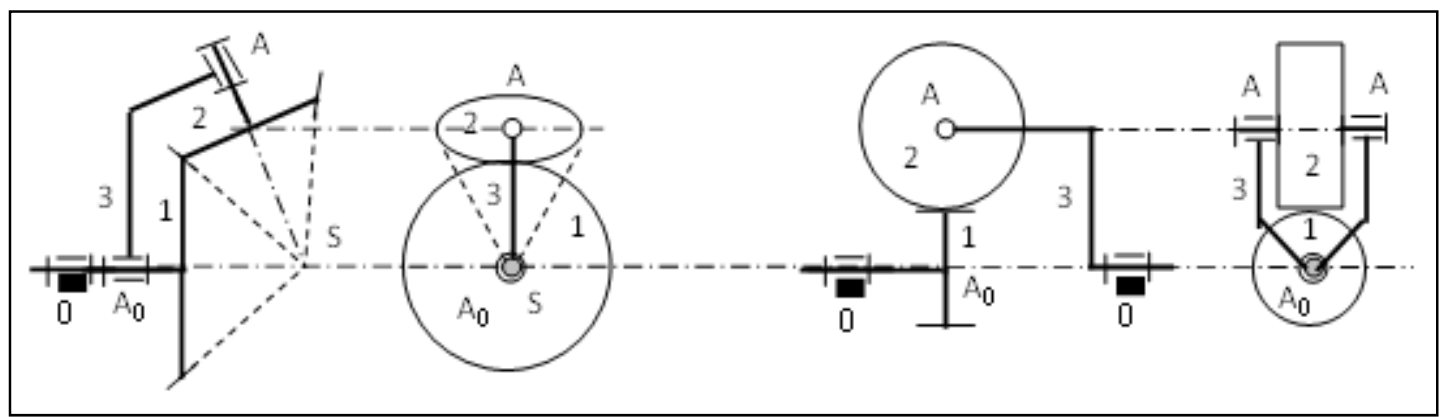

a)

b)

Figure 1: Elementary space mechanisms can be made with a single central wheel

The range of space associated with this kinematic contour is $r=3$, since the axes of the rotation $(m=1)$ and roto-translation $(m=2)$ are competing at point $S$.

Such a space mechanism with a bar and a conical gear is equivalent to a spherical spherical joint with monomobile joints, in which all axes are competing in the center $S$ of the sphere.

In the case of the worm gear (Figure 1b), the worm wheel 1 is a central wheel and forms a hypoid gear (worm) with the worm wheel 2, the axes of the two gears being crossed in the orthogonal position. The bar 3 has a fixed axle (denoted by $A_{0}$ ) common to that of the worm wheel 1 , and the mobile shaft of the joint $A$ (with the worm wheel) is orthogonal to the fixed one.

The mobility of the cross-axle space mechanism is $M=2$, resulting from the application of the formula (2) customized to the 6 :

$$
M=C_{1}+5 C_{5}-6 N_{6}=3+5 \cdot 1-6 \cdot 1=2
$$

In the application of the formula (2) it is mentioned that the engagement of the two worm wheels $(1,2)$ forms a pentamobile kemematic coupling $(m=5)$, at which the 
contact of the two surfaces is made at a point. A mechanism that includes a pentamobile kinematic coupling (maximum class) is associated with the maximum gradient $(r=6)$.

The space mechanism equivalent to this worm gear mechanism is an orthogonal spatial quadrilateral, the links of which are two trimmed spherical couplings and two monoblock rotation couplings.

The elementary space mechanisms with two central conical wheels (Figure 2) are obtained from the previous one (Figure 1a) by the addition of a conical gear wheel 4 , the axis of which is common to the fixed one.

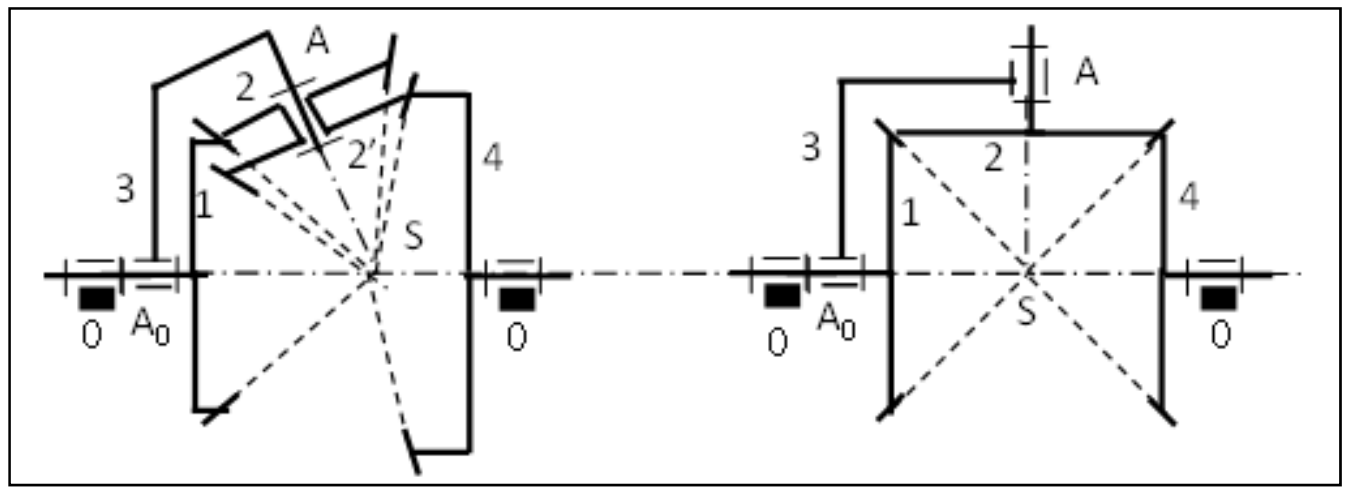

a)

b)

Figure 2: Elementary space mechanisms made with two central wheels

The first space mechanism (Figure 2a) contains a bar 3 and two conical gears $(1,2)$ and $(2,4)$ mounted in parallel. The mobility of the mechanism is $M=2$, this being calculated by the formula (3) for the particular case of the spherical mechanisms:

$$
M=C_{1}+2 C_{2}-3 N_{3}=4+2 \cdot 2-3 \cdot 2=2
$$

The second spatial mechanism (Figure $2 b$ ) is a particular case of the first mechanism from which it is obtained by orienting the movable axis in a direction perpendicular to the fixed axis.

In this latter case, the gears 1 and 4 are equal and the wheels 2 and 2 ' coincide, so that the two gears are mounted in series.

If the bar 3 is immobilized, the transmission ratio between wheels 1 and 4 is obtained as the product of the partial transmission reports to be written, in the general case (Figure 2a), according to the tooth numbers in the form of: 


$$
i_{14}^{3}=i_{12}^{3} \cdot i_{2^{\prime} 4}^{3}=-\frac{z_{2} \cdot z_{4}}{z_{1} \cdot z_{2^{\prime}}}
$$

For the particular case (fig. 2b), when $z_{2}=z_{2}$ and $z_{1}=z_{4}$, of the formula (4) results $i_{14}^{3}=-1$, that is to say, the central wheels 1 and 4 are rotating in the opposite direction, assuming that the bar 3 is immobilized.

The rotation of the bar 3 is transmitted to the central wheels 1 and 4 , so that the formula:

$$
i_{14}^{3}=\frac{\omega_{1}-\omega_{3}}{\omega_{4}-\omega_{3}}=-1
$$

we can deduce the relationship:

$$
\omega_{1}+\omega_{4}=2 \omega_{3}
$$

By immobilizing one of the two central wheels 1 or 4 , the mobility of the spatial mechanism becomes $M=1$. For example, if the wheel 4 is immobilized, by actuating the rod 3 the movement is multiplied to the central wheel 1 , whose angular velocity is:

$$
\omega_{1}=2 \omega_{3}
$$

what is obtained from (6) for $\omega_{4}=0$.

In this case, the relative angular velocity of the wheel 2 relative to the bar 3 is deduced by writing the transmission ratio between the wheels 2 and 4 under the immobilization of the bar 3:

$$
i_{24}^{3}=\frac{\omega_{2}-\omega_{3}}{\omega_{4}-\omega_{3}}=\frac{\omega_{23}}{-\omega_{3}}
$$

from which it results $\omega_{23}=-\omega_{3} \cdot i_{24}^{3}$. 


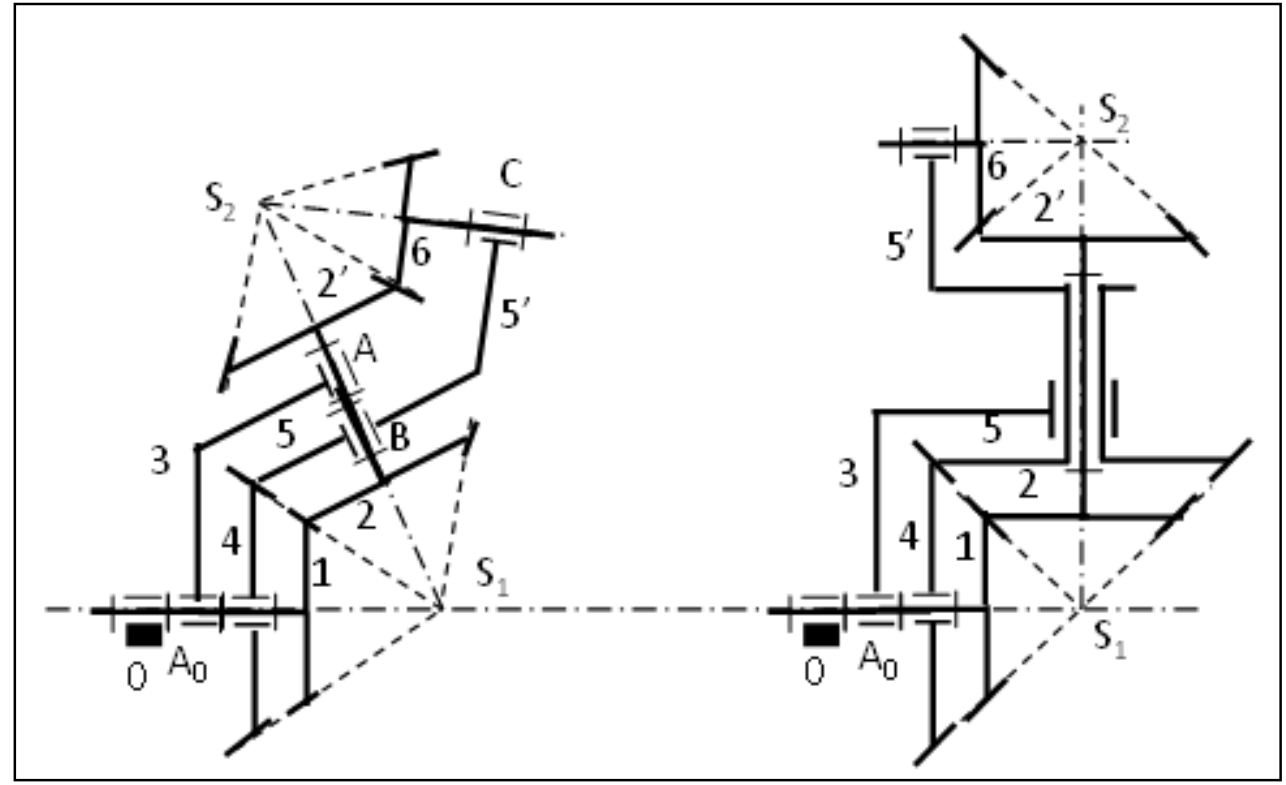

a)

b)

Figure 3: The space mechanism has at least two articulated bars

The spatial gear mechanisms with conical gears are obtained from the previously analyzed by the kinematic chaining operation with bars.

By means of overlaying, the space mechanism has at least two articulated bars (Figure 3), in which the conical gears are some (Figure 3a) or Orthogonal (Figure 3b).

The two kinematic schemes (Figure 3a, b) are isomorphic, having the same topological structure, two bars ( 3 and 5$)$ and three conical gears $(1,2),(4,5)$.

It is noted that the first two conical gears $(1,2)$ and $(4,5)$ have the misaligned axes, being competing in the $S 1$ point, and at the third conical gear $\left(2^{\prime}, 6\right)$ the axes intersect in $\mathrm{S}_{2}$.

Also, the toothed wheel 5 is integral with the $5^{\prime}$ bar that makes the wheel hinge 6. The mobility of the two complex space mechanisms is $M=3$, a value resulting from the calculation using the custom formula (9):

$$
M=C_{1}+2 C_{2}-3 N_{3}=6+2 \cdot 3-3 \cdot 3=3
$$

For the numerical calculation of formula (9), for each of the two kinematic schemes (figure 3), the following structural-topological parameters were identified:

$$
m=1, C_{1}=6 ; \quad m=2, C_{2}=3 ; \quad r=3, n=6, N_{3}=3
$$


DOI: 10.14807/ijmp.v10i5.902

According to each mobility, there is a distinct kinematic chain: the chain with bars $(0,3)$, the conical chain and bevel chain $\left(0,4,5-5^{\prime}\right)$ and the conical toothed wheel chain $(0,1,2-2 ', 6)$.

The three kinematic chains are linked together by the common axes, a movable one for three elements $(2,3,5)$ and another fixed for four elements $(0,1,3,4)$.

It is found that the three open kinematic outlines are partially coupled, so when the kinematic chain $(0,1,2-2 ', 6)$ is actuated, the other 2 chains are not driven in motion.

The action of the kinematic chain $\left(0,4,5-5^{\prime}\right)$ influences only the chain $(0,1,2-$ $2 ', 6)$, to which it imparts a first additional movement.

By moving the kinematic chain $(0,3)$, the motion is transmitted to the other two kinematic chains $\left(0,4,5-5^{\prime}\right)$ and $\left(0,1,2-2^{\prime}, 6\right)$ of which the last chain receives a second movement further.

The calculation algorithm in the kinematic analysis of this complex spatial mechanism (Figure 3), with mobility $\mathrm{M}=3$, highlights three phases of work:

I) $\omega_{1} \neq 0, \omega_{3}=0, \omega_{4}=0$, when computed:

$\omega_{65}^{I}=\omega_{1} \cdot i_{16}^{3,5}=-\omega_{1} \cdot \frac{z_{1} \cdot z_{2}}{z_{2} \cdot z_{6}}$

II) $\omega_{1}=0, \omega_{3}=0, \omega_{4} \neq 0$, when computed:

$\omega_{53}^{I I}=\omega_{1} \cdot \frac{z_{4}}{z_{5}} ; \omega_{65}^{I I}=\omega_{53}^{I I} \cdot \frac{z_{2^{\prime}}}{z_{6}}$

III) $\omega_{1}=0, \omega_{3} \neq 0, \omega_{4}=0$, when computed:

$\omega_{53}^{I I I}=-\omega_{3} \cdot \frac{z_{4}}{z_{5}} ; \omega_{2}^{I I I}=-\omega_{3} \cdot \frac{z_{1}}{z_{2}} ; \omega_{65}^{I I I}$

\section{RESULTS AND DISCUSSION; SPATIAL MECHANISMS WITH BARS AND CLOSED-CHAIN TOOTHED WHEELS}

This class of spatial mechanisms has, as a bar-shaped chain, a articulated spherical quadrangular contour $4 R, R C C R$ and RCCC spatial quadrilateral, RRCCR spherical and spatial pentalater, RRRCRR spatial hexalator and 7R spatial heptalater. 
INDEPENDENT JOURNAL OF MANAGEMENT \& PRODUCTION (IJM\&P)

http://Www.ijmp.jor.br

V. 10, n. 5, September-October 2019

ISSN: 2236-269X

DOI: 10.14807/ijmp.v10i5.902

\subsection{Spherical quadrangular space mechanisms.}

It is formed by overlapping the chain formed by two, three and four conical gears.

Gears are distinct cinematic elements or are mounted in solidarity with some bars of the spherical quadrangle contour.

It is considered the cranked spherical crank mechanism (figure 4) to which a conical gear, two or three conical gears are attached. The rocker bar $3\left(\mathrm{BB}_{0}\right)$ is perpendicular to the fixed rotation axis projecting at point $\mathrm{B}_{0}$.

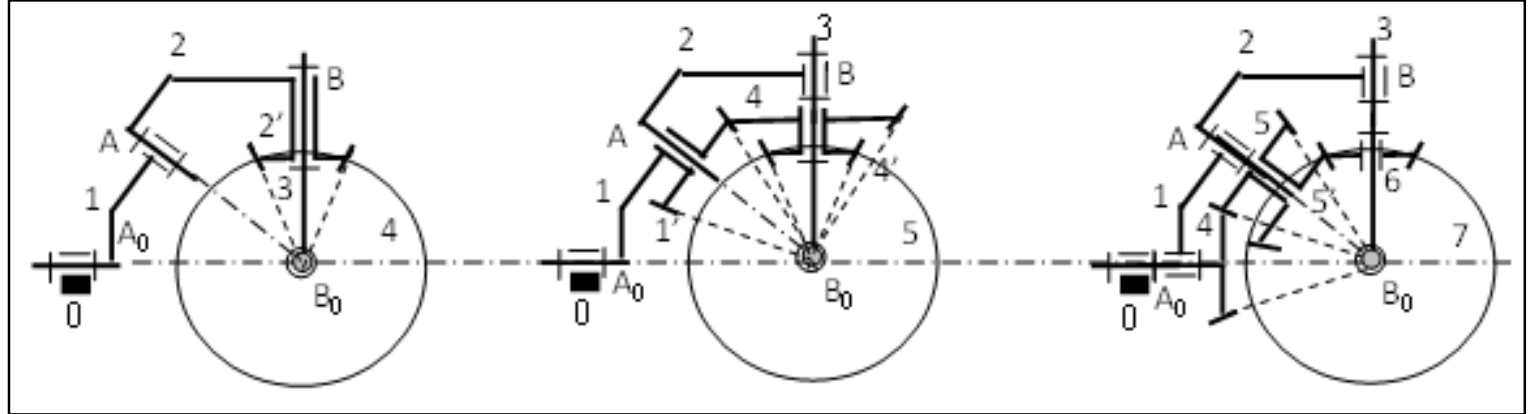

a) b) c)

Figure 4: It is considered the crank-type spherical gear mechanism to which is attached a conical gear, two or three conical gears

The variant 1 (figure $4 a$ ) is obtained by attaching the orthogonal conical gear $(2 ', 4)$ to the spherical $(0,1,2,3)$ quadrant so that the wheel $2^{\prime}$ is integral with the bar 2 and the wheel 4 has the axle fixed joint with that of bar 3 with oscillating rocker movement.

The mobility of the spherical spatial mechanism is $M=1$, it is calculated by the formula (14) as the particular form:

$$
M=C_{1}+2 C_{2}-3 N_{3}=5+2 \cdot 1-3 \cdot 2=1
$$

where the numerical values specific to the kinematic schemes (fig. 4a) were used (15):

$$
m=1, C_{1}=5 ; \quad m=2, C_{2}=1 ; \quad r=3, n=4, N_{3}=2
$$

The angular speed of the wheel 4 is calculated according to the angular speeds of the bars 2 and 3 and the transmission ratio of the conical gear $(2 ', 4)$.

Variant 2 (Figure 4b) is obtained by attaching to the articulated spherical quadrangle of the kinematic chain consisting of two conical gears $(1 ', 4)$ and $(4 ', 5)$, in 
INDEPENDENT JOURNAL OF MANAGEMENT \& PRODUCTION (IJM\&P)

http://www.ijmp.jor.br

V. 10, n. 5, September-October 2019

ISSN: 2236-269X

DOI: 10.14807/ijmp.v10i5.902

which the wheel $1^{\prime}$ is integral with the bar 1 . The gear $\left(1^{\prime}, 4^{\prime}\right)$ has the angle between the axes of wheels 1 ' and 4 equal to? $(\mathrm{ABOB})$ formed by the axes of the joints of $A$ and $B$. The gear $\left(4^{\prime}, 5\right)$ is also orthogonal. The mobility of the two-gear space mechanism is $M=1$, the value resulting from the calculation of formula (16) in the particular form:

$$
M=C_{1}+2 C_{2}-3 N_{3}=6+2 \cdot 2-3 \cdot 3=1
$$

in which the numerical values of the structural-topological parameters were replaced (17):

$$
m=1, C_{1}=6 ; \quad m=2, C_{2}=2 ; \quad r=3, n=5, N_{3}=3
$$

Variant 3 (Figure 4c) consists of three conical gears in which the wheel 4 is a distinct element with the common axis with the rod 1, the wheels $5\left(5^{\prime}\right)$ are freely mounted on the joint axis of $A$, the wheel 6 is mounted free on the joint axis of $B$ and the driven wheel 7 is freely mounted on the fixed shaft of the articulation of $B 0$. The mobility of this complex spatial mechanism is $M=2$, as it results from the numerical calculation using the custom formula (18):

$$
M=C_{1}+2 C_{2}-3 N_{3}=8+2 \cdot 3-3 \cdot 4=2
$$

where the values specific to the kinematic scheme were replaced (Figure 4c):

$$
m=1, C_{1}=8 ; \quad m=2, C_{2}=3 ; \quad r=3, n=7, N_{3}=4
$$

\subsection{Spatial mechanisms with quadrature chain RCCR type}

The kinematic chain is formed with two articulations at the base $\left(A_{0}, B_{0}\right)$ and two cylindrical couplings (A, B) with the orthogonal moving axes (Figure 5).

It starts from the RCCR space bar mechanism (Figure 5a) which turns the crank 1 rotation into a limited rotation of the rocker rod 3 . The fixed axes of joints of $A_{0}$ and $\mathrm{B}_{0}$ are perpendicular to non-competing or competing.

The bar 2 consists of two orthogonal segments in $S$, each having a direction parallel to the axis of one of the joints $A_{0}$ and $B_{0}$. These conditions determine the movement of the bar 2 , which is a circular translation in space. Since there is no rotation from the common normal to the fixed axes of $A_{0}$ and $B_{0}$, space associated with the spatial kinematic outline $(0,1,2,3)$ is $r=5$. 
DOI: 10.14807/ijmp.v10i5.902

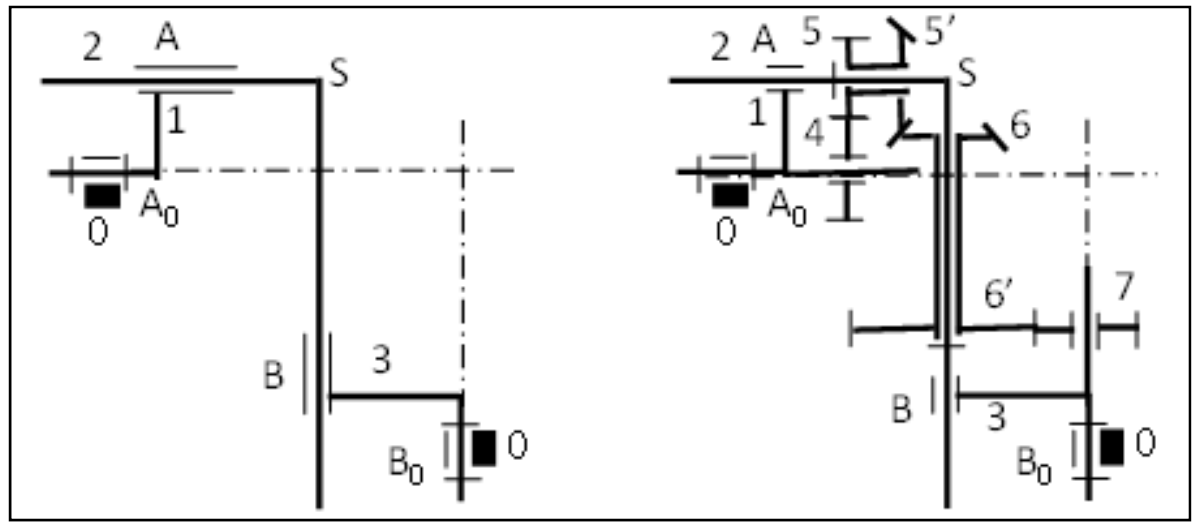

a)

b)

Figure 5: RCCR spacebar mechanism

The mobility of this mechanism is calculated by the formula (20) customized in the form:

$$
M=C_{1}+2 C_{2}-5 N_{5}=2+2 \cdot 2-5.1=1
$$

A kinematic chain with cylindrical gears $\left(4,5,6^{\prime}, 7\right)$ and conical $\left(5^{\prime}, 6\right)$ are attached to this kinematic chain $(0,1,2,3)$ with which they form the complex spatial mechanism with bars and gears (Figure $5 b$ ).

The mobility of the complex spatial mechanism is calculated with the formula (21) written in the form:

$$
M=C_{1}+2 C_{2}-\left(3 N_{3}+5 N_{5}\right)=6+2 \cdot 5-(3 \cdot 3+5 \cdot 1)=2
$$

It is to be noted that cylindrical gears 4 and 7 are connected by cylindrical couplers to the shafts of the respective joints of $A_{0}$ and $B_{0}$.

The two mobilities are identified at bar 1 (as a crank) and wheel 4 (as a rotation motion).

\subsection{Spatial mechanisms with RCCC quadrilateral chain}

The RCCC quadrilateral cinematic chain space mechanism (Figure 6a) has the axes arranged anyway in space, so that the additional chain will comprise hippocidal gears $(4,5)$ and $\left(5^{\prime}, 6\right)$ in which some hipod wheels along the axis of rotation (Figure $6 b)$. 
DOI: 10.14807/ijmp.v10i5.902

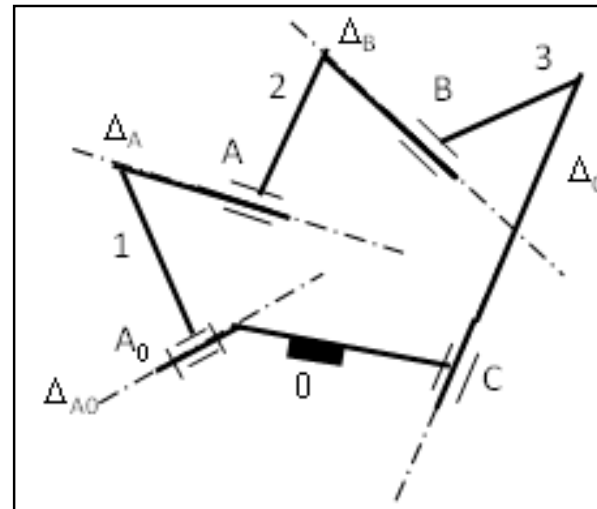

a)

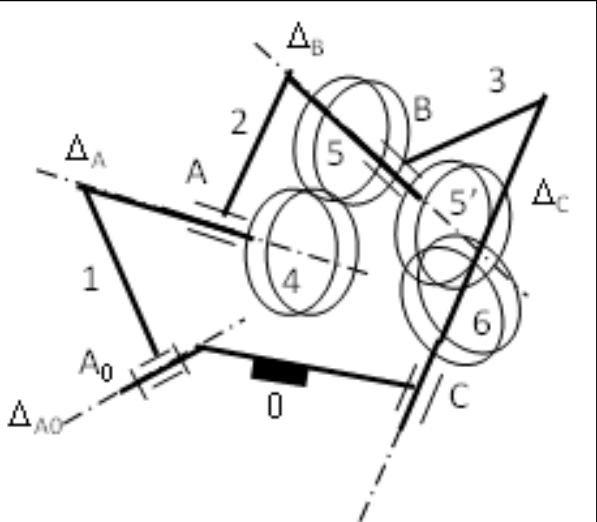

b)

Figure 6: The RCCC quadrilateral cinematic space mechanism

\subsection{Spatial heptalater chain mechanisms type $7 R$}

The kinematic chain with seven articulated bars forms a heptagon closed contour and has the seven axes of rotation disposed anyway in space (Figure 7a).

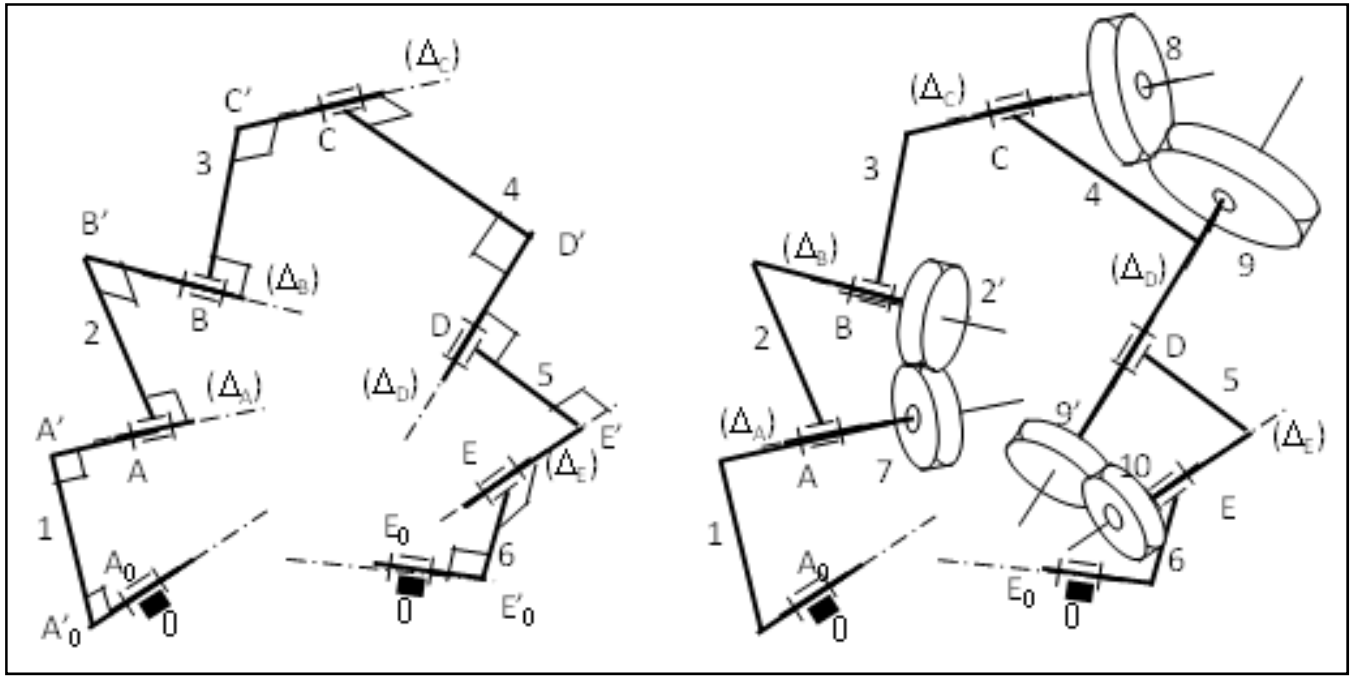

a)

b)

Figure 7: Spatial heptalater chain mechanisms type 7R

Each kinematic element is an articulated bar, the length of which corresponds to the common normal at two neighboring rotation axes, which are generally crossbars (nonconcurrent and nonparallel).

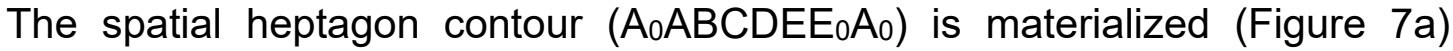
through the 13-sided spatial contour ( $\left.A^{\prime}{ }_{0} A^{\prime} A B^{\prime} B C^{\prime} C D^{\prime} D E^{\prime} E E^{\prime}{ }_{0} E 0 A^{\prime}{ }_{0}\right)$.

A closed cinema contour of seven bars, with the axes of any joints, corresponds to an associated maximum height space $(r=6)$. 
The range of the associated space is maximum $(r=6)$, even if some of the seven axes are concurrent or parallel.

Such an articulated space mechanism (with all seven kinematic couplings of class $m=1$ ) is structurally topological equivalent to a hypoid gear mechanism (with two couplings of class $m=1$ and a coupling of class $m=5$, represented by punctual contact of the surfaces of the conjugate teeth).

The mobility of the articulated space mechanism is $M=1$, which is verified by the calculation of the formula (22) customized as:

$$
M=C_{1}-6 N_{6}=7-6 \cdot 1=1
$$

One or more splice chains with hypoid gears are attached to this spatial kinematic chain (Figure 7b), the mechanism obtained is with bars and hyboidal teeth (hyperboloidal).

In the case considered (Fig. 7b), three hypoid gears were attached: the gear (7, 2 ') between the axles $\left(\Delta_{A}\right)$ and $\left(\Delta_{B}\right)$, the gear $(8,9)$ between the $\left.\left(\Delta_{C}\right) 9^{\prime}, 10\right)$ between $(\Delta \mathrm{D})$ and $(\Delta \mathrm{E})$.

By attaching the three hypoid gears, three contours of the highest rank are formed, so that the mobility of the complex space mechanism with bars and hypoid gears is calculated with the formula:

$$
M=C_{1}+5 C_{5}-6 N_{6}=11+5 \cdot 3-6 \cdot 4=2
$$

In applying the above formula, it has been taken into account that the wheels $7,8,9\left(9^{\prime}\right)$ and 10 are freely mounted on respective axes $(\Delta A),(\Delta c),(\Delta D)$ and $\left(\Delta_{E}\right)$.

\subsection{Space Spherical Mechanisms}

These spatial mechanisms are formed by attaching to a spherical pentagonal chain two or more conical gears, obtaining several variants with one, two or more mobility.

An example of a spherical cone with bevel gears and conical gears with mobility one is shown below (Figure 8a).

The kinematic spherical chain with articulated bars (Figure 8a) consists of movable elements 1, 2, 3 and 4 articulated between them and connected to the fixed 
DOI: 10.14807/ijmp.v10i5.902

element 0 by the orthogonal axes of $A_{0}$ and $C_{0}$. A kinematic chain with wheels consisting of three conical gears $\left(5,2^{\prime}\right),\left(2^{\prime}, 6\right)$ and $\left(6^{\prime}, 7\right)$ is attached to this kinematic chain.

The first two conical gears are represented in axial projection, and the third conical gear appears in transverse projection (Figure 8a). The conical gear $\left(66^{\prime}, 7\right)$ was also represented in axial projection (Figure 8b).

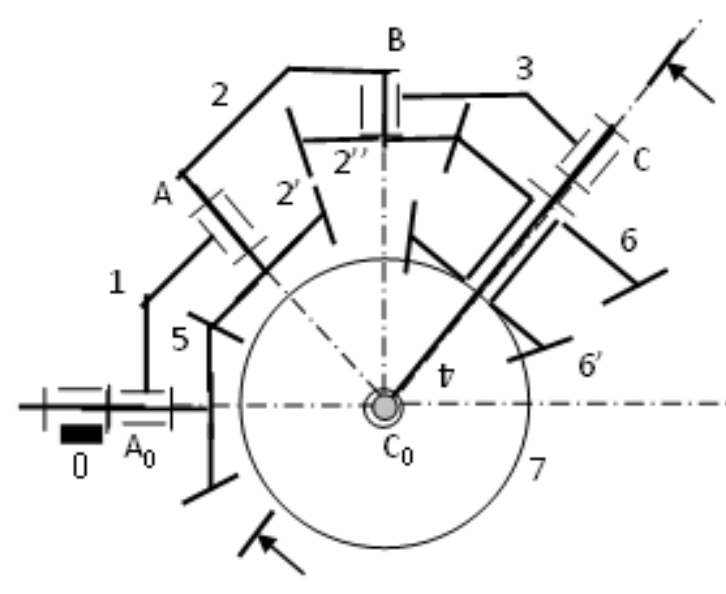

a)

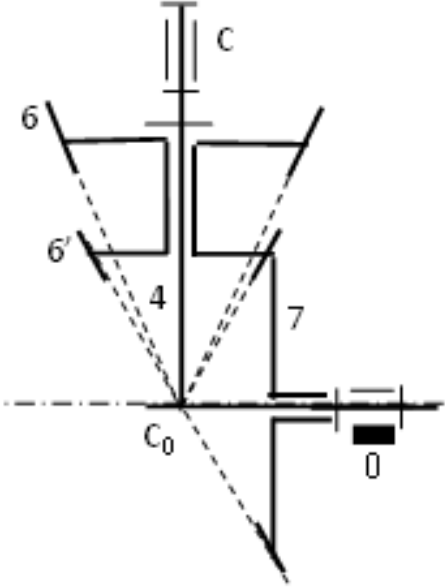

b)

Figure 8: Space Spherical Mechanisms

The mobility of the complex spherical mechanism is calculated using formula (24) in the particular form:

$$
M=C_{1}+2 C_{2}-3 N_{3}=8+2 \cdot 3-3 \cdot 4=2
$$

The two moves are represented by the independent rotation of the input elements (bar 1 and wheel 5), and the driven element is the toothed wheel 7.

\subsection{Spherical Hexalathar Spacing Mechanisms}

Starting from the 5-ball spherical mechanism attached to a kinematic chain with conical gears in several structural-topological variants, of which there is a variant with four conical gears (Figure 9) with the mobility $M=2$.

The rods and gears consist of at least one movable articulated bar and one of the cylindrical, tapered or hipoidal gears.

It is first considered the space mechanisms with the kernel chain with open bars. 
Two groups of such spatial mechanisms are known: elementary mechanisms (with a single articulated bar) and complex articulated mechanisms (with two or more articulated bars).

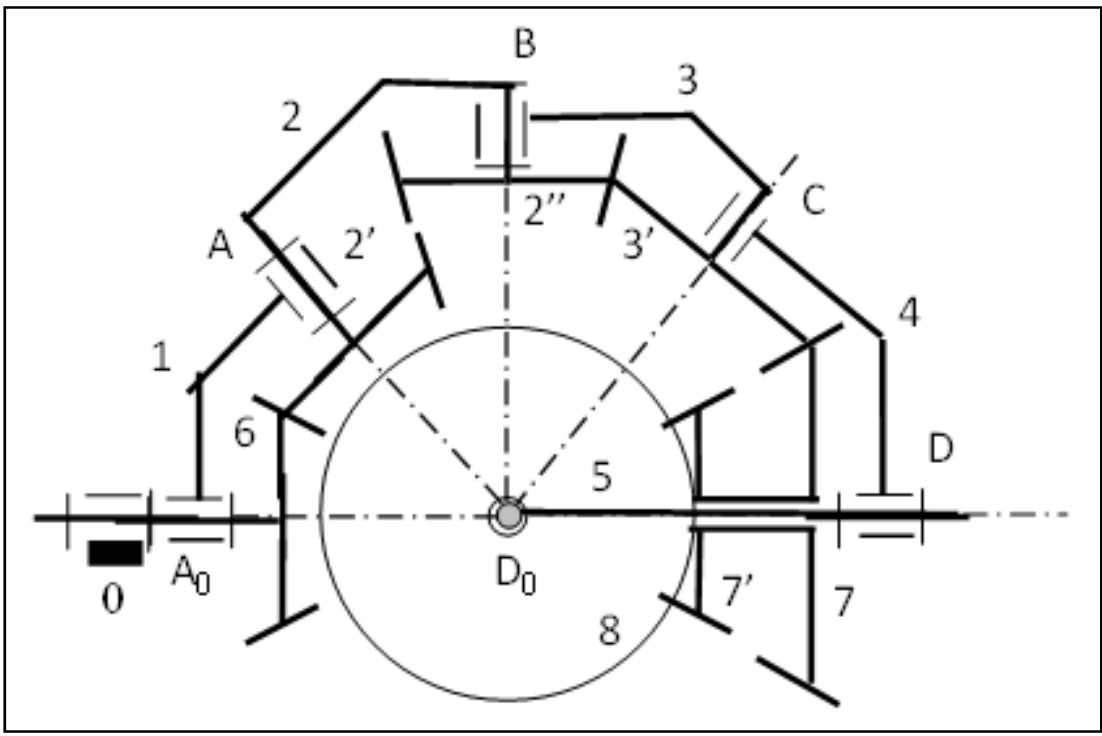

Figure 9: Spherical Hexalathar Spacing Mechanisms

Elementary space mechanisms can be made with a single central wheel (Figure 1) or two central wheels (Figure 2) whose fixed axes coincide with the axis of the fixed hinge of the bar.

The toothed wheels used in the space mechanisms are conical wheels (Figure 1a) and worm wheel with screw and worm wheel (Figure 1b).

In the spherical space mechanism (Figure 1a), the central conical wheel 1 engages the satellite cone wheel 2 , their axes being competing at the point $S$, this being the common tip of the rolling cones. The bar 3 has two joints, one fixed in $A 0$ (common to wheel 1), and another movable in A through which it links to wheel 2.

If the axes of the two conical wheels are perpendicular, the conical gear is called orthogonally, in this form being most often used in practice.

The mobility of the spherical mechanism is $M=2$, which is deduced by the calculation of the custom formula (1):

The range of space associated with this kinematic contour is $r=3$, since the axes of the rotation $(m=1)$ and roto-translation $(m=2)$ are competing at point $S$. 
INDEPENDENT JOURNAL OF MANAGEMENT \& PRODUCTION (IJM\&P)

http://Www.ijmp.jor.br

V. 10, n. 5, September-October 2019

ISSN: 2236-269X

DOI: 10.14807/ijmp.v10i5.902

Such a space mechanism with a bar and a conical gear is equivalent to a spherical spherical joint with monomobile joints, in which all axes are competing in the center $\mathrm{S}$ of the sphere.

In the case of the worm gear (Figure 1b), the worm wheel 1 is a central wheel and forms a hypoid gear (worm) with the worm wheel 2, the axes of the two gears being crossed in the orthogonal position. The bar 3 has a fixed axle (denoted by A0) common to that of the worm wheel 1 , and the mobile shaft of the joint $A$ (with the worm wheel) is orthogonal to the fixed one.

The mobility of the cross-axle space mechanism is $M=2$, resulting from the application of the formula (2) customized to the 6 :

In the application of the formula (2) it is mentioned that the engagement of the two worm wheels $(1,2)$ forms a pentamobile kemematic coupling $(m=5)$, at which the contact of the two surfaces is made at a point. A mechanism that includes a pentamobile kinematic coupling (maximum class) is associated with the maximum gradient $(r=6)$.

The space mechanism equivalent to this worm gear mechanism is an orthogonal spatial quadrilateral, the links of which are two trimmed spherical couplings and two monoblock rotation couplings.

The elementary space mechanisms with two central conical wheels (Figure 2) are obtained from the previous one (Figure 1a) by the addition of a conical gear wheel 4 , the axis of which is common to the fixed one.

The first space mechanism (Figure 2a) contains a bar 3 and two conical gears $(1,2)$ and $(2 ', 4)$ mounted in parallel. The mobility of the mechanism is $M=2$, this being calculated by the formula (3) for the particular case of the spherical mechanisms.

The second spatial mechanism (Figure 2b) is a particular case of the first mechanism from which it is obtained by orienting the movable axis in a direction perpendicular to the fixed axis.

In this latter case, the gears 1 and 4 are equal and the wheels 2 and 2' coincide, so that the two gears are mounted in series. 
If the bar 3 is immobilized, the transmission ratio between wheels 1 and 4 is obtained as the product of the partial transmission reports to be written, in the general case (Figure 2a), according to the tooth numbers in the form of.

By immobilizing one of the two central wheels 1 or 4 , the mobility of the spatial mechanism becomes $M=1$. For example, if the wheel 4 is immobilized, by actuating the rod 3 the movement is multiplied to the central wheel 1 , whose angular velocity is (7).

\section{CONCLUSIONS}

The rods and gears consist of at least one movable articulated bar and one of the cylindrical, tapered or hipoidal gears.

Only gears with circular or straight toothed gears, in which the relative position of the rotation or translation axes does not change, shall be considered.

The topological structure of the gears and gears is characterized by a kinematic chain with articulated bars and at least one kinematic chain with gears. The kinematic chain may be chain open (with a fixed rotation joint) or closed chain (with at least two fixed joints).

The kinematic chain with gears is attached to the kinematic chain with bars so that at least two gear wheels have centers in the bars of the bars and some wheels may be integral with the bars.

In practice, some of these gears with gears and gears are known as planetary gears with cylindrical, conical or hipoidal gears.

The gearing of these gears in these complex mechanisms is carried out in the form of series, parallel, or both parallel-series trains.

The system is made according to the articulated plan cinematic chain, which can be made as an open or closed kinematic chain.

\section{ACKNOWLEDGEMENT}

This text was acknowledged and appreciated by Dr. Veturia CHIROIU Honorific member of Technical Sciences Academy of Romania (ASTR) PhD supervisor in Mechanical Engineering. 


\section{FUNDING INFORMATION}

a) 1-Research contract: 1-Research contract: Contract number 36-5-4D/1986 from 24IV1985, beneficiary CNST RO (Romanian National Center for Science and Technology) Improving dynamic mechanisms.

b) 2-Contract research integration. 19-91-3 from 29.03.1991; Beneficiary: MIS; TOPIC: Research on designing mechanisms with bars, cams and gears, with application in industrial robots.

c) 3-Contract research. GR 69/10.05.2007: NURC in 2762; theme 8: Dynamic analysis of mechanisms and manipulators with bars and gears.

d) 4-Labor contract, no. 35/22.01.2013, the UPB, "Stand for reading performance parameters of kinematics and dynamic mechanisms, using inductive and incremental encoders, to a Mitsubishi Mechatronic System" "PN-II-IN-Cl-20121-0389".

e) All these matters are copyrighted! Copyrights: 394-qodGnhhtej, from 17-022010 13:42:18; 463-vpstuCGsiy, from 20-03-2010 12:45:30; 631-sqfsgqvutm, from 24-05-2010 16:15:22; 933-CrDztEfqow, from 07-01-2011 13:37:52.

\section{ETHICS}

Authors should address any ethical issues that may arise after the publication of this manuscript.

\section{REFERENCES}

ANTONESCU, P.; PETRESCU, F. I. T. (1985) An analytical method of synthesis of cam mechanism and flat stick. Proceedings of the 4th International Symposium on Theory and Practice of Mechanisms, (TPM' 89), Bucharest.

ANTONESCU, P.; PETRESCU, F. I. T. (1989) Contributions to kinetoplast dynamic analysis of distribution mechanisms. SYROM'89, Bucharest.

ANTONESCU, P.; OPREAN, M.; PETRESCU, F. I. T. (1985a) Contributions to the synthesis of oscillating cam mechanism and oscillating flat stick. Proceedings of the 4th International Symposium on Theory and Practice of Mechanisms, (TPM' 85), Bucharest.

ANTONESCU, P.; OPREAN, M.; PETRESCU, F. I. T. (1985b) At the projection of the oscillate cams, there are mechanisms and distribution variables. Proceedings of the 5th Conference of Engines, Automobiles, Tractors and Agricultural Machines, (TAM' 58), I-Motors and Cars, Brasov. 
ANTONESCU, P.; OPREAN, M.; PETRESCU, F. I. T. (1986) Projection of the profile of the rotating camshaft acting on the oscillating plate with disengagement. Proceedings of the 3rd National Computer-aided Design Symposium in the field of Mechanisms and Machine Parts, (MMP' 86), Brasov.

ANTONESCU, P.; OPREAN, M.; PETRESCU, F. I. T. (1987) Dynamic analysis of the cam distribution mechanisms. Proceedings of the 7th National Symposium on Industrial Robots and Space Mechanisms, (RSM' 87), Bucharest.

ANTONESCU, P.; OPREAN, M.; PETRESCU, F. I. T. (1988) Analytical synthesis of Kurz profile, rotating the flat cam. Mach, Build. Rev.

ANTONESCU, P.; PETRESCU, F. I. T.; ANTONESCU, O. (1994) Contributions to the synthesis of the rotating cam mechanism and the tip of the balancing tip. Brasov.

ANTONESCU, P.; PETRESCU, F. I. T.; ANTONESCU, O. (1997) Geometrical synthesis of the rotary cam and balance tappet mechanism. Bucharest, n. 3, p. 2323.

ANTONESCU, P.; PETRESCU, F. I. T.; ANTONESCU, O. 2000a. Contributions to the synthesis of the rotary disc-cam profile. Proceedings of the 8th International Conference on the Theory of Machines and Mechanisms, (TMM' 00), Liberec, Czech Republic, p. 51-56.

ANTONESCU, P.; PETRESCU, F. I. T.; ANTONESCU, O. (2000b) Synthesis of the rotary cam profile with balance follower. Proceedings of the 8th Symposium on Mechanisms and Mechanical Transmissions, (MMT' 00), Timişoara, p. 39-44.

ANTONESCU, P.; PETRESCU, F. I. T.; ANTONESCU, O. (2001) Contributions to the synthesis of mechanisms with rotary disc-cam. Proceedings of the 8th IFToMM International Symposium on Theory of Machines and Mechanisms, (TMM' 01), Bucharest, ROMANIA, p. 31-36.

ATEFI, G.; ABDOUS, M. A.; GANJEHKAVIRI, A. (2008) Analytical Solution of Temperature Field in Hollow Cylinder under Time Dependent Boundary Condition Using Fourier series, Am. J. Eng. Applied Sci., v. 1, n. 2, p. 141-148. DOI: 10.3844/ajeassp.2008.141.148

AVAEI, A.; GHOTBI, A. R.; ARYAFAR, M. (2008) Investigation of Pile-Soil Interaction Subjected to Lateral Loads in Layered Soils, Am. J. Eng. Applied Sci., v. 1, n. 1, p. 76-81. DOI: 10.3844/ajeassp.2008.76.81

AVERSA, R.; PETRESCU, R. V. V.; APICELLA, A.; PETRESCU, F. I. T. (2017a) Nano-diamond hybrid materials for structural biomedical application. Am. J.

Biochem. Biotechnol., n. 13, p. 34-41. DOI: 10.3844/ajbbsp.2017.34.41

AVERSA, R.; PETRESCU, R. V. V.; AKASH, B.; BUCINELL, R. B.; CORCHADO, J. M. (2017b) Kinematics and forces to a new model forging manipulator. Am. J.

Applied Sci., n. 14, p. 60-80. DOI: 10.3844/ajassp.2017.60.80

AVERSA, R.; PETRESCU, R. V. V.; APICELLA, A.; PETRESCU, F. I. T. CALAUTIT, J. K. (2017c) Something about the $V$ engines design. Am. J. Applied Sci., n. 14, p. 34-52. DOI: 10.3844/ajassp.2017.34.52 
INDEPENDENT JOURNAL OF MANAGEMENT \& PRODUCTION (IJM\&P)

http://Www.ijmp.jor.br

V. 10, n. 5, September-October 2019

ISSN: 2236-269X

DOI: 10.14807/ijmp.v10i5.902

AVERSA, R.; PARCESEPE, D.; PETRESCU, R. V. V.; BERTO, F.; CHEN, G. (2017d) Process ability of bulk metallic glasses. Am. J. Applied Sci., n. 14, p. 294301. DOI: 10.3844/ajassp.2017.294.301

AVERSA, R.; PETRESCU, R. V. V.; AKASH, B.; BUCINELL, R. B.; CORCHADO, J. M. (2017e) Something about the balancing of thermal motors. Am. J. Eng. Applied Sci., n. 10, p. 200-217. DOI: 10.3844/ajeassp.2017.200.217

AVERSA, R.; PETRESCU, F. I. T.; PETRESCU, R. V. V.; APICELLA, A. (2016a)

Biomimetic FEA bone modeling for customized hybrid biological prostheses development. Am. J. Applied Sci., n. 13, p. 1060-1067. DOI:

10.3844/ajassp.2016.1060.1067

AVERSA, R.; PARCESEPE, D.; PETRESCU, R. V. V.; G. CHEN, G. PETRESCU, F. I. T. (2016b) Glassy amorphous metal injection molded induced morphological defects. Am. J. Applied Sci., n. 13, p. 1476-1482. DOI:

10.3844/ajassp.2016.1476.1482

AVERSA, R.; PETRESCU, R. V. V.; PETRESCU, F. I. T.; and APICELLA, A.; 2016c. Smart-factory: Optimization and process control of composite centrifuged pipes. Am. J. Applied Sci., n. 13, p. 1330-1341. DOI:

10.3844/ajassp.2016.1330.1341

AVERSA, R.; TAMBURRINO, F.; PETRESCU, R. V. V.; PETRESCU, F. I. T.; ARTUR, M. (2016d) Biomechanically inspired shape memory effect machines driven by muscle like acting NiTi alloys. Am. J. Applied Sci., n. 13, p. 1264-1271. DOI: 10.3844/ajassp.2016.1264.1271

AVERSA, R.; BUZEA, E. M.; PETRESCU, R. V. V.; APICELLA, A.; NEACSA, M. (2016e) Present a mechatronic system having able to determine the concentration of carotenoids. Am. J. Eng. Applied Sci., n. 9, p. 1106-1111. DOI:

10.3844/ajeassp.2016.1106.1111

AVERSA, R.; PETRESCU, R. V. V.; SORRENTINO, R.; PETRESCU, F. I. T.; APICELLA, a. (2016f) Hybrid ceramo-polymeric nanocomposite for biomimetic scaffolds design and preparation. Am. J. Eng. Applied Sci., n. 9, p. 1096-1105. DOI: 10.3844/ajeassp.2016.1096.1105

AVERSA, R.; PERROTTA, V.; PETRESCU, R. V. V.; MISIANO, C.; PETRESCU, F. I. T. (2016g) From structural colors to super-hydrophobicity and achromatic transparent protective coatings: Ion plating plasma assisted $\mathrm{TiO}_{2}$ and $\mathrm{SiO}_{2}$ nano-film deposition. Am. J. Eng. Applied Sci., n. 9, p. 1037-1045. DOI:

10.3844/ajeassp.2016.1037.1045

AVERSA, R.; PETRESCU, R. V. V.; PETRESCU, F. I. T.; APICELLA, A. (2016h).

Biomimetic and evolutionary design driven innovation in sustainable products

development. Am. J. Eng. Applied Sci., n. 9, p. 1027-1036. DOI:

10.3844/ajeassp.2016.1027.1036

AVERSA, R.; PETRESCU, R. V. V.; APICELLA, A.; PETRESCU, F. I. T. (2016i)

Mitochondria are naturally micro robots - a review. Am. J. Eng. Applied Sci., 9: 9911002. DOI: $10.3844 /$ ajeassp.2016.991.1002

AVERSA, R.; PETRESCU, R. V. V.; APICELLA, A.; PETRESCU, F. I. T. (2016j) We are addicted to vitamins $C$ and E-A review. Am. J. Eng. Applied Sci., n. 9, p. 10031018. DOI: 10.3844/ajeassp.2016.1003.1018 
INDEPENDENT JOURNAL OF MANAGEMENT \& PRODUCTION (IJM\&P)

http://Www.ijmp.jor.br

V. 10, n. 5, September-October 2019

ISSN: 2236-269X

DOI: 10.14807/ijmp.v10i5.902

AVERSA, R.; PETRESCU, R. V. V.; APICELLA, A.; PETRESCU, F. I. T. (2016k) Physiologic human fluids and swelling behavior of hydrophilic biocompatible hybrid ceramo-polymeric materials. Am. J. Eng. Applied Sci., n. 9, p. 962-972. DOI: 10.3844/ajeassp.2016.962.972

AVERSA, R.; PETRESCU, R. V. V.; APICELLA, A.; PETRESCU, F. I. T. (2016I) One can slow down the aging through antioxidants. Am. J. Eng. Applied Sci., n. 9, p. 1112-1126. DOI: 10.3844/ajeassp.2016.1112.1126

AVERSA, R.; PETRESCU, R. V. V.; APICELLA, A.; PETRESCU, F. I. T. (2016m) About homeopathy or «Similia Similibus Curentur». Am. J. Eng. Applied Sci., n. 9, p. 1164-1172. DOI: 10.3844/ajeassp.2016.1164.1172

AVERSA, R.; PETRESCU, R. V. V.; APICELLA, A.; PETRESCU, F. I. T. (2016n) The basic elements of life's. Am. J. Eng. Applied Sci., n. 9, p. 1189-1197. DOI: 10.3844/ajeassp.2016.1189.1197

AVERSA, R.; PETRESCU, F. I. T.; PETRESCU, R. V. V.; APICELLA, A. (20160) Flexible stem trabecular prostheses. Am. J. Eng. Applied Sci., n. 9, p. 1213-1221. DOI: 10.3844/ajeassp.2016.1213.122

AZAGA, M.; OTHMAN, M. (2008) Source Couple Logic (SCL): Theory and Physical Design, Am. J. Eng. Applied Sci., v. 1, n. 1, p. 24-32. DOI: 10.3844/ajeassp.2008.24.32

CAO, W.; DING, H.; BIN, Z.; ZIMING, C. (2013) New structural representation and digital-analysis platform for symmetrical parallel mechanisms. Int. J. Adv. Robotic Sys. DOI: $10.5772 / 56380$

COMANESCU, A. (2010) Bazele Modelarii Mecanismelor. 1st Edn., E. Politeh, Press, Bucureşti, pp: 274.

DONG, H.; GIAKOUMIDIS, N.; FIGUEROA, N.; MAVRIDIS, N. (2013) Approaching behaviour monitor and vibration indication in developing a General Moving Object Alarm System (GMOAS). Int. J. Adv. Robotic Sys. DOI: 10.5772/56586

YOUSIF EL-TOUS, (2008) Pitch Angle Control of Variable Speed Wind Turbine, Am. J. Eng. Applied Sci., v. 1, n. 2, p. 118-120. DOI: 10.3844/ajeassp.2008.118.120

FRANKLIN, D. J. (1930) Ingenious Mechanisms for Designers and Inventors. 1st Edn., Industrial Press Publisher.

HE, B.; WANG, Z.; LI, Q.; XIE, H.; SHEN, R. (2013) An analytic method for the kinematics and dynamics of a multiple-backbone continuum robot. IJARS. DOI: $10.5772 / 54051$

JOLGAF, M.; SULAIMAN, S. B.; M.K.A ARIFFIN, M. K. A.; FAIEZA, A. A. (2008) Closed Die Forging Geometrical Parameters Optimization for Al-MMC, Am. J. Eng. Applied Sci., v. 1, n. 1, p. 1-6. DOI : 10.3844/ajeassp.2008.1.6

KANNAPPAN, A. N.; KESAVASAMY, R.; PONNUSWAMY, V. (2008) Molecular Interaction Studies of $\mathrm{H}$-Bonded Complexes of Benzamide in 1,4-Dioxan with Alcohols From Acoustic and Thermodynamic Parameters, Am. J. Eng. Applied Sci., v. 1 , n. 2, p. 95-99. DOI: 10.3844/ajeassp.2008.95.99

LEE, B. J. (2013) Geometrical derivation of differential kinematics to calibrate model parameters of flexible manipulator. Int. J. Adv. Robotic Sys. DOI: 10.5772/55592 
LIN, W.; LI, B.; YANG, X.; ZHANG, D. (2013) Modelling and control of inverse dynamics for a 5-DOF parallel kinematic polishing machine. Int. J. Adv. Robotic Sys. DOI: $10.5772 / 54966$

LIU, H.; ZHOU, W.; LAI, X.; ZHU, S. (2013) An efficient inverse kinematic algorithm for a PUMA560-structured robot manipulator. IJARS. DOI: 10.5772/56403

MEENA, P.; RITTIDECH, S. (2008) Comparisons of Heat Transfer Performance of a Closed-looped Oscillating Heat Pipe and Closed-looped Oscillating Heat Pipe with Check Valves Heat Exchangers, Am. J. Eng. Applied Sci., v. 1, n. 1, p. 7-11. DOI: 10.3844/ajeassp.2008.7.11

MEENA, P.; RITTIDECH, S.; TAMMASAENG, P. (2008) Effect of Inner Diameter and Inclination Angles on Operation Limit of Closed-Loop Oscillating Heat-Pipes with Check Valves, Am. J. Eng. Applied Sci., v. 1, n. 2, p. 100-103. DOI: 10.3844/ajeassp.2008.100.103

MIRSAYAR, M. M.; JONEIDI, V. A.; PETRESCU, R. V. V.; PETRESCU, F. I. T.; BERTO, F. (2017) Extended MTSN criterion for fracture analysis of soda lime glass. Eng. Fracture Mechan., n. 178, p. 50-59. DOI: 10.1016/j.engfracmech.2017.04.018 NG, K. C.; YUSOFF,M. Z.; MUNISAMY, K.; HASINI, H.; SHUAIB, N. H. (2008) Time-Marching Method for Computations of High-Speed Compressible Flow on Structured and Unstructured Grid, Am. J. Eng. Applied Sci., v. 1, n. 2, p. 89-94. DOI: 10.3844/ajeassp.2008.89.94

PADULA, F.; PERDEREAU, V. (2013) An on-line path planner for industrial manipulators. Int. J. Adv. Robotic Sys. DOI: 10.5772/55063

PANNIRSELVAM, N.; RAGHUNATH, P. N.; SUGUNA, K. (2008) Neural Network for Performance of Glass Fibre Reinforced Polymer Plated RC Beams, Am. J. Eng.

Applied Sci., v. 1, n. 1, p. 82-88. DOI: 10.3844/ajeassp.2008.82.88

PERUMAAL, S.; JAWAHAR, N. (2013) Automated trajectory planner of industrial robot for pick-and-place task. IJARS. DOI: 10.5772/53940

PETRESCU, F. I. T.; PETRESCU, R. V. V. (1995a) Contributions to optimization of the polynomial motion laws of the stick from the internal combustion engine distribution mechanism. Bucharest, n. 1, p. 249-256.

PETRESCU, F. I. T.; PETRESCU, R. V. V. (1995b) Contributions to the synthesis of internal combustion engine distribution mechanisms. Bucharest, n. 1, p. 257264.

PETRESCU, F. I. T.; PETRESCU, R. V. V. (1997a) Dynamics of cam mechanisms (exemplified on the classic distribution mechanism). Bucharest, n. 3, p. 353-358.

PETRESCU, F. I. T.; PETRESCU, R. V. V. (1997b) Contributions to the synthesis of the distribution mechanisms of internal combustion engines with a Cartesian coordinate method. Bucharest, n. 3, p. 359-364.

PETRESCU, F. I. T.; PETRESCU, R. V. V. (1997c) Contributions to maximizing polynomial laws for the active stroke of the distribution mechanism from internal combustion engines. Bucharest, n. 3, p. 365-370.

PETRESCU, F. I. T.; PETRESCU, R. V. V. (2000a) Synthesis of distribution mechanisms by the rectangular (Cartesian) coordinate method. Proceedings of the 
INDEPENDENT JOURNAL OF MANAGEMENT \& PRODUCTION (IJM\&P)

http://Www.ijmp.jor.br

V. 10, n. 5, September-October 2019

ISSN: 2236-269X

DOI: 10.14807/ijmp.v10i5.902

8th National Conference on International Participation, (CIP' 00), Craiova, Romania, p. 297-302.

PETRESCU, F. I. T.; PETRESCU, R. V. V. (2000b) The design (synthesis) of cams using the polar coordinate method (triangle method). Proceedings of the 8th National Conference on International Participation, (CIP' 00), Craiova, Romania, p. 291-296.

PETRESCU, F. I. T.; PETRESCU, R. V. V. (2002a) Motion laws for cams.

Proceedings of the International Computer Assisted Design, National Symposium Participation, (SNP' 02), Braşov, p 321-326.

PETRESCU, F. I. T.; PETRESCU, R. V. V. (2002b) Camshaft dynamics elements. Proceedings of the International Computer Assisted Design, National Participation Symposium, (SNP' 02), Braşov, p. 327-332.

PETRESCU, F. I. T.; PETRESCU, R. V. V. (2003) Some elements regarding the improvement of the engine design. Proceedings of the National Symposium, Descriptive Geometry, Technical Graphics and Design, (GTD' 03), Braşov, p. 353-358.

PETRESCU, F. I. T.; PETRESCU, R. V. V. (2005a) The cam design for a better efficiency. Proceedings of the International Conference on Engineering Graphics and Design, (EGD’ 05), Bucharest, p. 245-248.

PETRESCU, F. I. T.; PETRESCU, R. V. V. (2005b) Contributions at the dynamics of cams. Proceedings of the 9th IFToMM International Symposium on Theory of Machines and Mechanisms, (TMM' 05), Bucharest, Romania, p. 123-128.

PETRESCU, F. I. T.; PETRESCU, R. V. V. (2005c) Determining the dynamic efficiency of cams. Proceedings of the 9th IFToMM International Symposium on Theory of Machines and Mechanisms, (TMM' 05), Bucharest, Romania, p. 129134.

PETRESCU, F. I. T.; PETRESCU, R. V. V. (2005d) An original internal combustion engine. Proceedings of the 9th IFToMM International Symposium on Theory of Machines and Mechanisms, (TMM' 05), Bucharest, Romania, p. 135-140.

PETRESCU, F. I. T.; PETRESCU, R. V. V. (2005e) Determining the mechanical efficiency of Otto engine's mechanism. Proceedings of the 9th IFToMM International Symposium on Theory of Machines and Mechanisms, (TMM 05), Bucharest, Romania, p. 141-146.

PETRESCU, F. I. T.; PETRESCU, R. V. V. (2011a) Mechanical Systems, Serial and Parallel (Romanian). 1st Edn., LULU Publisher, London, UK, p. 124.

PETRESCU, F. I. T.; PETRESCU, R. V. V. (2011b) Trenuri Planetare. Createspace Independent Pub., 104 pages, ISBN-13: 978-1468030419.

PETRESCU, F. I. T.; PETRESCU, R. V. V. (2012a) Kinematics of the planar quadrilateral mechanism. ENGEVISTA, n. 14, p. 345-348.

PETRESCU, F. I. T.; PETRESCU, R. V. V. (2012b) Mecatronica-Sisteme Seriale si Paralele. 1st Edn., Create Space Publisher, USA, p. 128.

PETRESCU, F. I. T.; PETRESCU, R. V. V. (2013a) Cinematics of the 3R dyad. ENGEVISTA, n. 15, p. 118-124. 
INDEPENDENT JOURNAL OF MANAGEMENT \& PRODUCTION (IJM\&P)

http://Www.ijmp.jor.br

V. 10, n. 5, September-October 2019

ISSN: 2236-269X

DOI: 10.14807/ijmp.v10i5.902

PETRESCU, F. I. T.; PETRESCU, R. V. V. (2013b) Forces and efficiency of cams. Int. Rev. Mechanical Eng.

PETRESCU, F. I. T.; PETRESCU, R. V. V. (2016a) Parallel moving mechanical systems kinematics. ENGEVISTA, n. 18, p. 455-491.

PETRESCU, F. I. T.; PETRESCU, R. V. V. (2016b) Direct and inverse kinematics to the anthropomorphic robots. ENGEVISTA, n. 18, p. 109-124.

PETRESCU, F. I. T.; PETRESCU, R. V. V. (2016c) Dynamic cinematic to a structure 2R. Revista Geintec-Gestao Inovacao E Tecnol., n. 6, p. 3143-3154.

PETRESCU, F. I. T.; GRECU, B.; COMANESCU, A.; PETRESCU, R. V. V. (2009) Some mechanical design elements. Proceeding of the International Conference on Computational Mechanics and Virtual Engineering, (MVE' 09), Braşov, p. 520-525.

PETRESCU, F. I. T. (2011) Teoria Mecanismelor si a Masinilor: Curs Si Aplicatii. 1st Edn., CreateSpace Independent Publishing Platform. ISBN-10: 1468015826. P. 432.

PETRESCU, F. I. T. (2015a) Geometrical synthesis of the distribution mechanisms. Am. J. Eng. Applied Sci., n. 8, p. 63-81. DOI: 10.3844/ajeassp.2015.63.81

PETRESCU, F. I. T. 2015b. Machine motion equations at the internal combustion heat engines. Am. J. Eng. Applied Sci., 8: 127-137. DOI:

10.3844/ajeassp.2015.127.137

PETRESCU, R. V. V.; AVERSA, R.; APICELLA, A.; PETRESCU, F. I. T. (2016)

Future medicine services robotics. Am. J. Eng. Applied Sci., n. 9, p. 1062-1087.

DOI: 10.3844/ajeassp.2016.1062.1087

PETRESCU, R. V. V.; AVERSA, R.; AKASH, B.; BUCINELL, R.; CORCHADO, J. (2017a) Yield at thermal engines internal combustion. Am. J. Eng. Applied Sci., n. 10, p. 243-251. DOI: 10.3844/ajeassp.2017.243.251

PETRESCU, R. V. V.; AVERSA, R.; AKASH, B.; RONALD, B.; CORCHADO, J.( 2017b) Velocities and accelerations at the 3R mechatronic systems. Am. J. Eng. Applied Sci., n. 10, p. 252-263. DOI: 10.3844/ajeassp.2017.252.263

PETRESCU, R. V. V.; AVERSA, R.; AKASH, B.; BUCINELL, R.; CORCHADO, J. (2017c) Anthropomorphic solid structures n-r kinematics. Am. J. Eng. Applied Sci., n. 10, p. 279-291. DOI: 10.3844/ajeassp.2017.279.291

PETRESCU, R. V. V.; AVERSA, R.; AKASH, B.; BUCINELL, R.; CORCHADO, J. 2017d. Inverse kinematics at the anthropomorphic robots, by a trigonometric method. Am. J. Eng. Applied Sci., n. 10, p. 394-411. DOI:

10.3844/ajeassp.2017.394.411

PETRESCU, R. V. V.; AVERSA, R.; AKASH, B.; BUCINELL, R.; CORCHADO, J. (2017e) Forces at internal combustion engines. Am. J. Eng. Applied Sci., n. 10, p. 382-393. DOI: 10.3844/ajeassp.2017.382.393

PETRESCU, R. V. V.; AVERSA, R.; AKASH, B.; BUCINELL, R.; CORCHADO, J. (2017f) Gears-Part I. Am. J. Eng. Applied Sci., n. 10, p. 457-472. DOI:

10.3844/ajeassp.2017.457.472 
INDEPENDENT JOURNAL OF MANAGEMENT \& PRODUCTION (IJM\&P)

http://Www.ijmp.jor.br

V. 10, n. 5, September-October 2019

ISSN: 2236-269X

DOI: 10.14807/ijmp.v10i5.902

PETRESCU, R. V. V.; AVERSA, R.; AKASH, B.; BUCINELL, R.; CORCHADO, J. (2017g) Gears-part II. Am. J. Eng. Applied Sci., n. 10, p. 473-483. DOI: 10.3844/ajeassp.2017.473.483

PETRESCU, R. V. V.; AVERSA, R.; AKASH, B.; BUCINELL, R.; CORCHADO, J. (2017h). Cam-gears forces, velocities, powers and efficiency. Am. J. Eng. Applied Sci., n. 10, p. 491-505. DOI: 10.3844/ajeassp.2017.491.505

PETRESCU, R. V. V.; AVERSA, R.; AKASH, B.; BUCINELL, R.; CORCHADO, J. (2017i) Dynamics of mechanisms with cams illustrated in the classical distribution. Am. J. Eng. Applied Sci., n. 10, p. 551-567. DOI: 10.3844/ajeassp.2017.551.567

PETRESCU, R. V. V.; AVERSA, R.; AKASH, B.; BUCINELL, R.; CORCHADO, J. (2017j) Testing by non-destructive control. Am. J. Eng. Applied Sci., n. 10, p. 568583. DOI: $10.3844 /$ ajeassp.2017.568.583

PETRESCU, R. V. V.; AVERSA, R.; APICELLA, A.; and PETRESCU, F. I. T.; 2017k. Transportation engineering. Am. J. Eng. Applied Sci., n. 10, p. 685-702. DOI: 10.3844/ajeassp.2017.685.702

PETRESCU, R. V. V.; AVERSA, R.; KOZAITIS, S.; APICELLA, A.; PETRESCU, F. I. T. (2017I) The quality of transport and environmental protection, part I. Am. J. Eng. Applied Sci., n. 10, p. 738-755. DOI: 10.3844/ajeassp.2017.738.755

PETRESCU, R. V. V.; AVERSA, R.; AKASH, B.; R. BUCINELL, R.; CORCHADO, J. $(2017 \mathrm{~m})$ Modern propulsions for aerospace-a review. J. Aircraft Spacecraft Technol., n. 1, p. 1-8. DOI: 10.3844/jastsp.2017.1.8

PETRESCU, R. V. V.; AVERSA, R.; AKASH, B.; BUCINELL, R.; CORCHADO, J. (2017n) Modern propulsions for aerospace-part II. J. Aircraft Spacecraft Technol., n. 1, p. 9-17. DOI: 10.3844/jastsp.2017.9.17

PETRESCU, R. V. V.; AVERSA, R.; AKASH, B.; BUCINELL, R.; CORCHADO, J. (2017o) History of aviation-a short review. J. Aircraft Spacecraft Technol., n. 1, p. 30-49. DOI: 10.3844/jastsp.2017.30.49

PETRESCU, R. V. V.; AVERSA, R.; AKASH, B.; BUCINELL, R.; CORCHADO, J. (2017p) Lockheed martin-a short review. J. Aircraft Spacecraft Technol., n. 1, p. 5068. DOI: 10.3844/jastsp.2017.50.68

PETRESCU, R. V. V.; AVERSA, R.; AKASH, B.; BUCINELL, R.; CORCHADO, J. (2017q) Our universe. J. Aircraft Spacecraft Technol., n. 1, p. 69-79. DOI: 10.3844/jastsp.2017.69.79

PETRESCU, R. V. V.; AVERSA, R.; AKASH, B.; CORCHADO, J.; BERTO, F. (2017r) What is a UFO? J. Aircraft Spacecraft Technol., n. 1, p. 80-90. DOI: 10.3844/jastsp.2017.80.90

PETRESCU, R. V. V.; AVERSA, R.; AKASH, B.; CORCHADO, J.; BERTO, F. (2017s) About bell helicopter FCX-001 concept aircraft-a short review. J. Aircraft Spacecraft Technol., n. 1, p. 91-96. DOI: 10.3844/jastsp.2017.91.96

PETRESCU, R. V. V.; AVERSA, R.; AKASH, B.; CORCHADO, J.; BERTO, F. (2017t) Home at airbus. J. Aircraft Spacecraft Technol., n. 1, p. 97-118. DOI: 10.3844/jastsp.2017.97.118 
INDEPENDENT JOURNAL OF MANAGEMENT \& PRODUCTION (IJM\&P)

http://Www.ijmp.jor.br

V. 10, n. 5, September-October 2019

ISSN: 2236-269X

DOI: 10.14807/ijmp.v10i5.902

PETRESCU, R. V. V.; AVERSA, R.; AKASH, B.; CORCHADO, J.; BERTO, F. (2017u) Airlander. J. Aircraft Spacecraft Technol., n. 1, p. 119-148. DOI: 10.3844/jastsp.2017.119.148

PETRESCU, R. V. V.; ERSA, R.; AKASH, B.; CORCHADO, J.; BERTO, F. (2017v) When boeing is dreaming-a review. J. Aircraft Spacecraft Technol., n. 1, p. 149-161. DOI: 10.3844/jastsp.2017.149.161

PETRESCU, R. V. V.; AVERSA, R.; AKASH, B.; CORCHADO, J.; BERTO, F.( 2017w) About Northrop Grumman. J. Aircraft Spacecraft Technol., n. 1, p. 162-185. DOI: 10.3844/jastsp.2017.162.185

PETRESCU, R. V. V.; AVERSA, R.; AKASH, B.; CORCHADO, J.; BERTO, F. (2017x) Some special aircraft. J. Aircraft Spacecraft Technol., n. 1, p. 186-203. DOI: 10.3844/jastsp.2017.186.203

PETRESCU, R. V. V.; AVERSA, R.; AKASH, B.; CORCHADO, J.; BERTO, F. (2017y) About helicopters. J. Aircraft Spacecraft Technol., n. 1, p. 204-223. DOI: 10.3844/jastsp.2017.204.223

PETRESCU, R. V. V.; AVERSA, R.; AKASH, B.; BERTO, F.; APICELLA, A. (2017z) The modern flight. J. Aircraft Spacecraft Technol., n. 1, p. 224-233. DOI: 10.3844/jastsp.2017.224.233

PETRESCU, R. V. V.; AVERSA, R.; AKASH, B.; BERTO, F.; APICELLA, A. (2017aa) Sustainable energy for aerospace vessels. J. Aircraft Spacecraft Technol., n. 1, p. 234-240. DOI: 10.3844/jastsp.2017.234.240

PETRESCU, R. V. V.; AVERSA, R.; AKASH, B.; BERTO, F.; APICELLA, A. (2017ab) Unmanned helicopters. J. Aircraft Spacecraft Technol., n. 1, p. 241-248. DOI: 10.3844/jastsp.2017.241.248

PETRESCU, R. V. V.; AVERSA, R.; AKASH, B.; BERTO, F.; APICELLA, A. (2017ac) Project HARP. J. Aircraft Spacecraft Technol., n. 1, p. 249-257. DOI: 10.3844/jastsp.2017.249.257

PETRESCU, R. V. V.; AVERSA, R.; AKASH, B.; BERTO, F.; APICELLA, A. (2017ad) Presentation of Romanian engineers who contributed to the development of global aeronautics-part I. J. Aircraft Spacecraft Technol., n. 1, p. 258-271. DOI: 10.3844/jastsp.2017.258.271

PETRESCU, R. V. V.; AVERSA, R.; AKASH, B.; BERTO, F.; APICELLA, A. (2017ae) A first-class ticket to the planet mars, please. J. Aircraft Spacecraft Technol., n. 1, p. 272-281. DOI: 10.3844/jastsp.2017.272.281

PETRESCU, R. V. V.; AVERSA, R.; APICELLA, A.; MIRSAYAR, M. M.; KOZAITIS, S. (2018a) NASA started a propeller set on board voyager 1 after 37 years of break. Am. J. Eng. Applied Sci., n. 11, p. 66-77. DOI: 10.3844/ajeassp.2018.66.77

PETRESCU, R. V. V.; AVERSA, R.; APICELLA, A.; MIRSAYAR, M. M.; KOZAITIS, S. (2018b) There is life on mars? Am. J. Eng. Applied Sci., n. 11, p. 78-91. DOI: 10.3844/ajeassp.2018.78.91

PETRESCU, R. V. V.; AVERSA, R.; APICELLA, A.; PETRESCU, F. I. T. (2018c) Friendly environmental transport. Am. J. Eng. Applied Sci., n. 11, p. 154-165. DOI: 10.3844/ajeassp.2018.154.165 
INDEPENDENT JOURNAL OF MANAGEMENT \& PRODUCTION (IJM\&P)

http://Www.ijmp.jor.br

V. 10, n. 5, September-October 2019

ISSN: 2236-269X

DOI: 10.14807/ijmp.v10i5.902

PETRESCU, R. V. V.; AVERSA, R.; AKASH, B.; ABU-LEBDEH, T. M.; T. M.; APICELLA, A. (2018d) Buses running on gas. Am. J. Eng. Applied Sci., n. 11, p. 186-201. DOI: 10.3844/ajeassp.2018.186.201

PETRESCU, R. V. V.; AVERSA, R.; AKASH, B.; ABU-LEBDEH, T. M.; T. M.; APICELLA, A. (2018e) Some aspects of the structure of planar mechanisms. Am. J. Eng. Applied Sci., n. 11, p. 245-259. DOI: 10.3844/ajeassp.2018.245.259

PETRESCU, R. V. V.; AVERSA, R.; ABU-LEBDEH, T. M.; APICELLA, A.; PETRESCU, F. I. T. (2018f) The forces of a simple carrier manipulator. Am. J. Eng. Applied Sci., n. 11, p. 260-272. DOI: 10.3844/ajeassp.2018.260.272

PETRESCU, R. V. V.; AVERSA, R.; ABU-LEBDEH, T. M.; APICELLA, A.; PETRESCU, F. I. T. (2018g) The dynamics of the otto engine. Am. J. Eng. Applied Sci., n. 11, p. 273-287. DOI: 10.3844/ajeassp.2018.273.287

PETRESCU, R. V. V.; AVERSA, R.; ABU-LEBDEH, T. M.; APICELLA, A.; PETRESCU, F. I. T. (2018h) NASA satellites help us to quickly detect forest fires. Am. J. Eng. Applied Sci., n. 11, p. 288-296. DOI: 10.3844/ajeassp.2018.288.296

PETRESCU, R. V. V.; AVERSA, R.; ABU-LEBDEH, T. M.; APICELLA, A.; PETRESCU, F. I. T. (2018i) Kinematics of a mechanism with a triad. Am. J. Eng. Applied Sci., n. 11, p. 297-308. DOI: 10.3844/ajeassp.2018.297.308

PETRESCU, R. V. V.; AVERSA, R.; APICELLA, A.; PETRESCU, F. I. T. (2018j) Romanian engineering "on the wings of the wind". J. Aircraft Spacecraft Technol., n. 2, p. 1-18. DOI: 10.3844/jastsp.2018.1.18

PETRESCU, R. V. V.; AVERSA, R.; APICELLA, A.; PETRESCU, F. I. T. (2018k) NASA Data used to discover eighth planet circling distant star. J. Aircraft

Spacecraft Technol., n. 2, p. 19-30. DOI: 10.3844/jastsp.2018.19.30

PETRESCU, R. V. V.; AVERSA, R.; APICELLA, A.; PETRESCU, F. I. T. (2018I) NASA has found the most distant black hole. J. Aircraft Spacecraft Technol., n. 2, p. 31-39. DOI: 10.3844/jastsp.2018.31.39

PETRESCU, R. V. V.; AVERSA, R.; APICELLA, A.; PETRESCU, F. I. T. (2018m) Nasa selects concepts for a new mission to titan, the moon of saturn. J. Aircraft Spacecraft Technol., 2: 40-52. DOI: 10.3844/jastsp.2018.40.52

PETRESCU, R. V. V.; AVERSA, R.; APICELLA, A.; PETRESCU, F. I. T. (2018n) NASA sees first in 2018 the direct proof of ozone hole recovery. J. Aircraft

Spacecraft Technol., n. 2, p. 53-64. DOI: 10.3844/jastsp.2018.53.64

POURMAHMOUD, N. (2008) Rarefied Gas Flow Modeling inside Rotating Circular Cylinder, Am. J. Eng. Applied Sci., v. 1, n. 1, p. 62-65. DOI:

10.3844/ajeassp.2008.62.65

RAJASEKARAN, A.; RAGHUNATH, P. N.; SUGUNA, K. (2008) Effect of Confinement on the Axial Performance of Fibre Reinforced Polymer Wrapped RC Column, Am. J. Eng. Applied Sci., v. 1, n. 2, p. 110-117. DOI:

10.3844/ajeassp.2008.110.117

SHOJAEEFARD, M. H.; GOUDARZI, K.; NOORPOOR, A. R.; FAZELPOUR, M. (2008) A Study of Thermal Contact using Nonlinear System Identification Models, Am. J. Eng. Applied Sci., v. 1, n. 1, p. 16-23. DOI: 10.3844/ajeassp.2008.16.23 
TAHER, S. A.; HEMATTI, R.; NEMATI, M. (2008) Comparison of Different Control Strategies in GA-Based Optimized UPFC Controller in Electric Power Systems, Am. J. Eng. Applied Sci., v. 1, n. 1, p. 45-52. DOI: 10.3844/ajeassp.2008.45.52

TAVALLAEI, M. A.; TOUSI, B. (2008) Closed Form Solution to an Optimal Control Problem by Orthogonal Polynomial Expansion, Am. J. Eng. Applied Sci., v. 1, n. 2, p. 104-109. DOI: 10.3844/ajeassp.2008.104.109

THEANSUWAN, W.; TRIRATANASIRICHAI, K. (2008) Air Blast Freezing of Lime Juice: Effect of Processing Parameters, Am. J. Eng. Applied Sci., v. 1, n. 1, p. 3339. DOI: 10.3844/ajeassp.2008.33.39

ZAHEDI, S. A.; VAEZI, M.; TOLOU, N. (2008) Nonlinear Whitham-Broer-Kaup Wave Equation in an Analytical Solution, Am. J. Eng. Applied Sci., v. 1, n. 2, p. 161-167. DOI: 10.3844/ajeassp.2008.161.167

ZULKIFLI, R.; SOPIAN, K.; ABDULLAH, S.; TAKRIFF, M. S. (2008) Effect of Pulsating Circular Hot Air Jet Frequencies on Local and Average Nusselt Number, Am. J. Eng. Applied Sci., v. 1, n. 1, p. 57-61. DOI: 10.3844/ajeassp.2008.57.61

\section{SOURCE OF FIGURES:}

Petrescu and Petrescu, 2011b. 